Rev. Saúde públ., s. Paulo

I(1):110, 1967.

\title{
MODIFICAÇAOO DO AGAR FENIL-ALANINA USADO NA IDENTIFICAÇÃO DE ENTERABACTERIÁCEAS (1)
}

\author{
Nota Técnica
}

Sebastião Timo IARIA

Luis COTILLO $\mathrm{Z}$.

\begin{abstract}
Droposta uma modificação da fórmula do agar fenil-alanina, com a finalidade de simplificar a prova da desaminação dêste aminoácido, que consiste na adigăo de citrato de ferro amoniacal ao meio.
\end{abstract}

A prova da desaminação da fenil-alanina, quando realizada pela técnica descrita por Ewing et alii (1957), requer após a incubação do meio inoculado, a junção de solução de tricloreto férrico para evidenciar a formação do ácido fenil-pirúvico como resultado da ação da desaminase das bactérias dos grupos Proteus e Providencia.

A simples adição de citrato de ferro amoniacal ao agar fenil-alanina, quando ainda na fase de preparação, permite simplificação da prova. 0 meio assim modificado, semeado com bactérias dos grupos Proteus e Providencia e incubado a $37^{\circ} \mathrm{C}$, após algumas horas se apresenta de côr marrom. Se inoculado com outras enterobacteriáceas nenhuma modificação de côr é observada.

A fórmula do meio proposto por EwING et alii (1957), foi por nós modificada da seguinte maneira:

\begin{tabular}{|c|c|}
\hline \multicolumn{2}{|l|}{$\begin{array}{l}\text { Extrato de levêdo (Difco) } \\
\text { DL fenil-alanina... }\end{array}$} \\
\hline DL fenil-alanina .. & 2,0 \\
\hline ou $L$ fenil-alanina & \\
\hline Fosfato dissódico & 1 , \\
\hline Citrato de ferro amoniacal & \\
\hline Cloreto de sódio & 5,0 \\
\hline
\end{tabular}

Agar (Difco)

Agua

$12,0 \mathrm{~g}$

$1.000 \mathrm{ml}$

Após a esterilização, a $120^{\circ} \mathrm{C}$ por 10 minutos, da mistura dos ingredientes necessários ao preparo do meio, segundo a fórmula original, foram adicionados $0,2 \%$ de citrato de ferro amoniacal e em seguida procedeu-se a distribuição em tubos, mantendo-os em posição inclinada. Este meio conserva-se bem por 4 a 6 dias, quando conservado em geladeira a $4^{\circ} \mathrm{C}$.

\section{S U M M A R Y}

A modification of the phenylalanine agar medium is proposed. The objective is the simplification of the deamination test. The modification consist in adding ferric ammonium citrate to the medium.

\section{REFERENCIA BIBLIOGRAFICA}

EWING, W. H, et alli apud EDWARDS, P. R. \& EWING, W. H. - Identification of enterobacteriaceae. [2nd ed.]. Minneapolis, Minn., Burgess Publ. [c. 1962]. p. 253.

Recebido para publicação em 31-7-1967.

(1) Da Cadeira de Microbiologia e Imunologia Aplicadas da Faculdade de Higiene e Saúde Pública da USP. 